\title{
EFFECT OF USING BIOCHAR AND ITS AQUEOUS EXTRACT ON SEEDLING PRODUCTION OF SOME VEGETABLE CROPS AND REFLECT THAT ON THE YIELD
}

\author{
Usrya A.I. Byan and Nahed M.M. El-Shimi \\ Veg. Res. Dept., Hort. Res. Inst., Agric. Res. Cent., Giza, Egypt
}

Key Words: Biochar, Aqueous extract, Nursery, Tomato, Sweet pepper, Cucumber, Lettuce, Growth, Yield

\begin{abstract}
This study was carried out during the two successive seasons of 2018 and 2019 at the Experimental Farm, Kaha station, Qulubia Governorate to confirm the effect of different rates of biochar $(0 \%$ biochar (control), 20\% biochar, 40\% biochar and 60\% biochar) mixture with commercial media (peat moss and vermiculite (1:1 volume basis) and two concentration from aqueous extract of biochar $(2 \%$ and $4 \%)$ as foliar spray on seed germination period and seedling growth parameters of tomato, sweet pepper, cucumber and lettuce and behavior of seedlings growth under the irrigation daily or every two days and study effect of that on the vegetative growth and total yield of sweet pepper plants. Biochar produced from gazwarina trees wood. Generally, it is clear that adding the low rate of biochar $(20 \%)$ to growing media significantly affected positively on germination percentage, germination rate and coefficient germination velocity for all previous crops this was true in both growing season. Regarding to tomato, cucumber and lettuce seedling, the results showed that adding the low rate of biochar $(20 \%)$ to growing media and irrigation daily or two days significantly affected positively on all vegetative growth and root growth characters followed by using aqueous extract of biochar at $2 \%$ as foliar spray and irrigation daily or two day treatments. While, the best treatments were foliar spray by aqueous extract of biochar at $4 \%, 2 \%$ followed by $40 \%$ and $20 \%$ biochar addition to growing media, respectively according to sweet pepper seedling. Generally, the effect of used different rates of biochar under two periods of irrigation induced significant effect on all vegetative growth, root growth parameters and leaf chlorophyll concentration of all previous crops seedling as grown in the nursery. It can be observed that with all biochar rates except addition the high rate of biochar $(60 \%)$ to growing media which significantly negative affected on all vegetative growth and root growth characters, this was true in both growing season.
\end{abstract}


The data reveal also that, generally, all studied plant growth parameters and total yield of sweet pepper plant, were significantly increased by using all different biochar rates especially the plants obtained from seedlings sprayed by aqueous extract of biochar at $2 \%$ or at $4 \%$ in both growing seasons.

In general these results demonstrate that in nursery plant propagation, biochar may be a beneficial amendment for standard growing media, potentially bringing benefits to plant productivity and reducing reliance on non-renewable media components or the higher coast.

\section{INTRODUCTION}

Few studies were conducted to assess the impact of biochar on seed germination as well as enhancing the agriculture soil and plant growth which due to the specificity of the interaction between biochars and plants.

Tomato, sweet pepper, cucumber and lettuce are four of the most popular and versatile vegetables in the world. Tomato (Solanum Lycopersicon) and sweet pepper (Capsicum annuum L.) are an excellent source of vitamins, minerals (Potassium, Calcium, Magnesium and Phosphor) and antioxidants such as lycopin pigment which conceder anti prostate cancer and contain salicylate compound. Cucumber (Cucumis sativus L.) is very high in water content and very low in calories. It has potential ant diabetic, lipid lowering and antioxidant activity. Lettuce (Lactuca sativa L.) contains Vitamin A, Vitamin C, Minerals, Water and Fibber. Pepper seed germination is considered a critical step in the development cycle of the plant, germination rate and seedling growth in pepper plants are very low comparing with the other vegetable seedlings. (Korkmaz and Korkmaz, 2009). Different pretreatments have been investigated to improving rate of pepper seeds germination and seedling growth, some of these treatments are chemical and others are natural product such as biochar.

Local alternatives for some inorganic components of growing media, such as vermiculite or perlite that are mined and often shipped great distances, are also being sought, especially given that the costs of some commonly used amendments, such as vermiculite, continue to climb Landis and Morgan (2008). Peat is still available in large quantities and modern horticulture depends on quality-assured growing media (Schmilewski, 2008 and Michel, 2010). Biochar has emerged as one such material that shows promise as a partial replacement of those media components, including perlite (Northup 2013), vermiculite (Headlee et al 2014 and Nemati et al. 2015) and peat (Vaughn et al. 2015 and Matt et al. 2018), one alternative to inorganic and organic constituents in growing media for plants is biochar. 
Biochar is a product of pyrolysis which is rich in carbon content and produced by heating biomass such as wood, manure or leaves in a closed container with little or no available air. In other words, it is produced by the thermal decomposition of organic material under a limited supply of $(\mathrm{O} 2)$ oxygen, and at relatively low temperatures $(<700$ $\mathrm{C}^{\circ}$ ) (Lehmann and Joseph 2009 and Sohi et al. 2010). Biochar has the potential to become a new technology employed in agricultural systems, since it has the capacity to increase nutrient availability in many soil types but there was little evidence to support the hypothesis of increased seed germination with the addition of biochar. Researchers observed species-dependent effects of biochar on the germination ( Keller et al., 2010, Kwapinski et al., 2010, Van Zwieten et al., 2010, Solaiman et al., 2012, Dumroese et al 2011, Robertson et al., 2012, Kamara et al., 2014 and Soni, et al., 2014).Biochar application significantly increases the early growth of seedlings (Thomas and Gale 2015). So it is crucial to study the impact of biochar on early growth of seedlings. Generally, biochar has the ability to enhance crop productivity. Moreover, biochar contains a high concentration of stable organic carbon (C) as well as eluted carbon and ash. Several macro and microelements can be stored in the mineral fraction of biochar which may act as a source of mineral substances for microorganisms in soil (Saletnik et al. 2016)

On the other side, biochar could be one of the solutions as it improves soil physical properties and aids in improving soil hydrology. Biochar is a finely divided pyrolysed material prepared for soil improvement. Due to negatively charged surfaces and high surface area, biochar soil amendments improved water holding capacity of soil and thus protected the crops against drought, while minimized the soil hardening and hence reduced soil bulk density (Ernsting, 2011). Successful seed germination is crucial for both plant growth and development; therefore, germination rate and early growth characteristics can be an early indicator of the effects of biochar on plant productivity (Rogovska et al., 2011). In this regard Northup (2013) showed that, plants grown in media containing biochar at 30\% blended with $70 \%$ sphagnum peat were the best compared to plants grown in a commercial substrate that contained sphagnum peat, perlite, and limestone. Many biochar based substrates produced plants with shoot dry mass greater than the control. These results demonstrate the potential for biochar to replace perlite and eliminate the limestone amendment needed for commercial greenhouse soilless substrates based on sphagnum peat. Carter et al.(2013) studied the effect of rice-husk char (potentially biochar) application on the growth of transplanted lettuce (Lactuca sativa) and cabbage they indicated that, the biochar treatments were found to increase the final biomass, root biomass, plant height and 
number of leaves in all the cropping cycles in comparison to no biochar treatments. Biochar had an effect on water relations, increasing relative water content and leaf osmotic potential, decreasing stomatal resistance and stimulating foliar (transpiration) gas exchange, and on photosynthesis by increasing the electron transport rate of photo system and the relation between effective photochemical quantum yield and nonphotochemical quenching(Haider, et al., 2015).

Hafeez et al. (2017) indicated that under water stress seed vigor, germination percentage, shoot length, membrane stability index, chlorophyll contents of soybean seedlings decreased significantly compared to control. However biochar applied proved to be more effective in mitigating the drought stress impacts in all these parameters. Moreover, Khan et al (2019) reported that, biochar significantly improved shoot and root dry weights, biomass and altered chlorophyll contents of tomato seedlings. Also, Uslu et al. (2020) demonstrated that biochar could increase seed germination percentage and seedling growth as well as vigor index with appropriate application rates.

Produce healthy seedlings under good nursery management is an important part of successful vegetable production. Major research interests have been directed to study biochar effects on soil quality and crop response, but little information is available about their possible effects on seed germination and seedling growth of vegetables crops.

The purpose of this study was to evaluate the effect of biochar rates on seed germination and seedling growth of tomato, sweet pepper, cucumber and lettuce as well as reflect of that on growth and yield of sweet pepper plants.

\section{MATERIALS AND METHODS}

\section{The First study}

\section{I.The nursery experiment}

The present study were conduct at the experimental Farm of Kaha vegetable research Station, Qalubia Governorate, Egypt, seeds of tomato (Solanum Lycopersicon L. cv. Super Strain B) sweet pepper (Capsicum annum L. cv. California Wonder), cucumber (Cucumis sativus L.Hybrid Mayson) and lettuce (Lactuca sativa L. cv.Landrace Lettuce) were sown under plastic house in the nursery during both 2018 and 2019seasons. The first part of nursery experiment aim to study the effect of adding different rates of biochar mixture with commercial media (peat moss and vermiculite (1:1 volume basis) as nursery substrate on seed germination parameters. Seeds of the previous plants were sown in the nursery, on the first week of January 2018and 2019 for both seasons, in foam trays (84 eyes for cucumber and lettuce) and (209 eyes for tomato and sweet pepper) filled with a mixture of commercial media and biochar were adequate amounts of fertilizers and fungicide, calcium carbonate was 
added to modify the mixture $\mathrm{pH}$. This experiment was distributed in randomized complete design with three replicates and included four treatments as follows $(0 \%$ biochar $+100 \%$ commercial media (control), $20 \%$ biochar $+80 \%$ commercial media, $40 \%$ biochar $+60 \%$ commercial media and $60 \%$ biochar $+40 \%$ commercial media). The seeds were considered germinated when the radical was at least $2 \mathrm{~mm}$ long (Al Harbi et al., 2008).

The purpose of the second part of nursery experiment was to study the response of tomato, sweet pepper, cucumber and lettuce seedlings to the different rates of biochar mixture with commercial media(peat moss and vermiculite (1:1 volume basis) and two concentration of aqueous extract of biochar as foliar spray under two periods of irrigation (daily and every two days). Seedling trays were kept under green-house conditions with all agriculture managements required for the production of whole seedlings except the irrigation periods. This experiment was distributed in randomized complete design with three replicates and included twelve treatments as follows.

1-0\% biochar (100\% commercial media) + daily irrigation (control)

2-20\% biochar adding to $80 \%$ commercial media + daily irrigation

3-40\% biochar adding to $60 \%$ commercial media + daily irrigation

4-60\% biochar adding to $40 \%$ commercial media + daily irrigation

5-2\% biochar extract as foliar spray+ daily irrigation

6-4 \% biochar extract as foliar spray+ daily irrigation

7-0\% biochar (100\% commercial media)+ irrigation every two days

8-20\% biochar adding to $80 \%$ commercial media + irrigation every two days

9-40\% biochar adding to $60 \%$ commercial media + irrigation every two days

10-60\% biochar adding to $40 \%$ commercial media + irrigation every two days

11-2 \% biochar extract as foliar spray+ irrigation every two days

12-4 \% biochar extract as foliar spray+ irrigation every two days.

Table (1): Cost of treatments used in this study

\begin{tabular}{|c|c|}
\hline Treatments & Cost of growing media (£E /ton) \\
\hline 0\% biochar (100\% commercial media) & $\mathbf{6 0 0 0}$ \\
\hline $20 \%$ biochar & 5250 \\
\hline $40 \%$ biochar & 4500 \\
\hline $60 \%$ biochar & 3750 \\
\hline
\end{tabular}

Commercial media (peat moss and vermiculite $(1: 1$ volume basis) $=6000$ (£E /ton), Biochar $=1400(\mathfrak{E} /$ ton $)$ 


\section{Preparation of biochar extract:}

The effect of the aqueous extractsin this study was examined at two concentrations of 2 and $4 \%$.Twenty grams for $2 \%$ or forty grams for $4 \%$ of dried powder from biochar were placed in a Erlenmeyer flask and then $1000 \mathrm{~mL}$ of distilled water was added and boiled for half hour. After shaking for 2 hours at $120 \mathrm{rev} \mathrm{min}^{-1}$ in the dark, the mixtures were filtered through Whatman No. 2 filter paper and then through a membrane filter with $0.45 \mu \mathrm{M}$ pore-size Taek-Keun et al (2012). The $\mathrm{pH}$ and EC were measured with a $\mathrm{pH}$ meter (Orion 3-star, Thermo Scientific, USA) and an EC meter (Orion 3-star, Thermo Scientific, USA), respectively.

\section{Table (2) Aqueous pH and EC values of different biochar rates}

\begin{tabular}{|c|c|c|c|c|}
\hline \multirow[t]{2}{*}{ Biochar rates } & \multicolumn{2}{|r|}{ pH } & \multicolumn{2}{|c|}{$\operatorname{EC}\left(d S ~ m^{-1}\right)$} \\
\hline & $\begin{array}{l}\text { Before } \\
\text { sowing }\end{array}$ & $\begin{array}{c}\text { Before } \\
\text { transplanting }\end{array}$ & $\begin{array}{l}\text { Before } \\
\text { sowing }\end{array}$ & $\begin{array}{c}\text { Before } \\
\text { transplanting }\end{array}$ \\
\hline $0 \%$ biochar $(100 \%$ commercial media) & 7.13 & 7.79 & 0.81 & 0.88 \\
\hline $\begin{array}{l}20 \% \text { biochar adding to } \\
80 \% \text { commercial media }\end{array}$ & 7.14 & 7.85 & 1.00 & 0.95 \\
\hline $\begin{array}{l}40 \% \text { biochar adding to } \\
60 \% \text { commercial media }\end{array}$ & 7.18 & 7.89 & 1.04 & 0.97 \\
\hline $\begin{array}{l}60 \% \text { biochar adding to } \\
40 \% \text { commercial media }\end{array}$ & 7.21 & 8.17 & 1.13 & 1.06 \\
\hline $2 \%$ biochar extract & \multicolumn{2}{|r|}{7.64} & \multicolumn{2}{|r|}{1.23} \\
\hline $4 \%$ biochar extract & \multicolumn{2}{|r|}{7.66} & \multicolumn{2}{|r|}{1.35} \\
\hline
\end{tabular}

Table (3): Chemical and physical characteristics of biochar produced from gazwarina trees wood.

\begin{tabular}{|l|c|}
\hline \multicolumn{1}{|c|}{ Characters } & Concentration \\
\hline Moisture content \% & 3.5 \\
\hline Ash content \% & 3.3 \\
\hline Bulk density kg m- ${ }^{3}$. & 560 \\
\hline EC $\left(\mathbf{d S ~ m}^{-1}\right)$ & 1.3 \\
\hline pH & 7.6 \\
\hline Total organic carbon\% & 94 \\
\hline Total Nitrogen\% & 1.12 \\
\hline C:N Ratio & $\mathbf{8 3 . 9}$ \\
\hline Total Phosphorus\% & 0.106 \\
\hline Total Potassium\% & 2.9 \\
\hline Calcium\% & 1.1 \\
\hline Magnesium\% & 0.36 \\
\hline Cation exchangeable capacity mmolc $\mathrm{kg}^{-1}$ & 16 \\
\hline
\end{tabular}

\section{Data recorded:}

-The germination percentage (number of germinated seeds was recorded each day during the period of the germination). 
-The germination rate (number of days required for maximum germination), according to Ranal and Santana (2006). Germination rate $=$ $(\mathrm{G} 1 \mathrm{~T} 1+\mathrm{G} 2 \mathrm{~T} 2+\ldots+\mathrm{GnTn}) /(\mathrm{G} 1+\mathrm{G} 2+\ldots+\mathrm{Gn})$, Where G: number of germination seeds per day and $\mathrm{T}$ : time.

-Coefficient germination velocity: $\Sigma \mathrm{Ni} / \Sigma$ NiTX 100

$\mathrm{Ni}$ : number of germination seeds per day and $\mathrm{T}$ : number of days from the start of count until the end according to Ranal and Santana (2006).

Ten seedlings were chosen randomly from each treatment in the three replicates after 35, 35, 45 and 55 day (age of seedling transplanting) from sowing for cucumber, lettuce, tomato and sweet pepper, respectively in order to determine the following:

-Seedlings length (the length of stem $\mathrm{cm}$ ) -Number of leaves/ seedling- Stem diameter cm - Seedlings fresh weight (g) - Total leaf chlorophyll concentration was measured using Minolta chlorophyll Meter SPAD- 501 as SPAD units- Root volume $\left(\mathrm{cm}^{3}\right)$ by using graduated cylinder - Root length (cm) - Root fresh weight (g).

\section{The second study}

II-Field experiment for planting the sweet pepper seedlings in the field:

The experiment was conducted at the Experimental Farm of Kaha vegetable research Station, Qalubia Governorate, Egypt. Soil was clay in texture with $7.6 \mathrm{ph}, 1.43 \%$ organic matters, $3.3 \mathrm{Ec}, 121 \mathrm{ppm} \mathrm{N}, 52 \mathrm{ppm} P$ and $109 \mathrm{ppm} \mathrm{K}$. The present investigation was conducted during two successive summer seasons of 2018 and 2019.

After 55 day from sowing healthy sweet pepper seedlings obtained from the first study were selected and transplanted on the field plot. The experiment was arranged in randomized complete block with three replicates and included twelve treatments asshowed in the nursery experiment. The plot area was $8.4 \mathrm{~m}^{2}$ and includes 3 ridges each of $0.7 \mathrm{~m}$ width and $4.0 \mathrm{~m}$ length

All agricultural practices were followed according to the recommendation for sweet pepper plantation. The following data were recorded as follows:

\section{Data recorded:}

Three plants were chosen randomly from each treatment in the three replicates after 75days from transplanting in order to determine the following:

-Plant length (the length of main stem $\mathrm{cm}$ ) -Stem diameter $(\mathrm{cm})$ - No. of. leaves/ plant - No. of. brunches/ plant and The leaf area was calculated according to the following formula of Wallace and Munger (1965):

-Leaf area $\left(\mathrm{cm}^{2}\right)=$ Leaves dry weight $(\mathrm{gm}) \times$ disk area / Disk dry weight (gm)

- Total fruit yield (ton/fed) after finishing the fruit pickings 
Statistical Analysis: The experimental design of this trial was randomized complete design for nursery experiment and randomized complete block for field experiment with three replicates. The obtained data were statistically analyzed using Duncan's multiple range tests at $\mathrm{P} \leq 0.05$ level to verify differences among treatment means according to Snedecor and Cochran (1982).

The first study:

$$
\text { RESULTS AND DISCUSSION }
$$

\section{I-The nursery experiment}

I.1. Germination percentage, germination rate and coefficient germination velocity of tomato, sweet pepper, cucumber and lettuce seeds.

Data in Table (4) revealed that, seeds of tomato, cucumber and lettuce grown in commercial media without biochar (control) or those media supplemented with lowest levels of biochar at $20 \%$ resulted the best values of germination percentage and reduced the time requirement for germination(germination rate).While the opposite was happened with the high level $(60 \%)$ of biochar which recorded significant reductions in germination percentage and coefficient of germination velocity occurred, while the time required for seed germination (germination rate) was increased, this results may be due to the high rates of biochar which lead to increase in $\mathrm{pH}$ in growing media as shown in Table (2).In this regard A dose-dependent negative effect on germination and seedling growth was found by (Solaiman et al. 2012). The inhibition of seedlings may be attributed to the reduced rate of cell division and cell elongation. Concerning the coefficient germination velocity of the same three crops data cleared that, there is no significant differences between the commercial added with biochar at 20 or $40 \%$ and without addition (control) while the level $60 \%$ gave negative effect. Regarding to sweet pepper seeds in the nursery showed that, all different rates of biochar led to increase in germination percentage and coefficient of germination velocity especially adding biochar at $20 \%$ or $40 \%$ rates to growing media comparing with control treatment ( $0 \%$ biochar ), this was true in both growing season .Generally, it is clear that adding the low rate of biochar $(20 \%)$ to growing media significantly positive affected on germination parameters, this was true in both growing season. The researchers observed species-dependent effects of biochar on the germination which they found that there is no negative impact of biochar on the germination (Keller et al., 2010, Kwapinski et al., 2010, Van Zwieten et al., 2010, Solaiman et al., 2012, Dumroese et al 2011, Robertson et al., 2012, Kamara et al., 2014 and Soni, et al., 2014). Moreover, Biochar application significantly increases the early growth of seedlings (Thomas and Gale 2015). Also, Uslu et al. (2020) demonstrated that biochar could increase seed germination percentage and seedling growth as well as vigor index with appropriate application rates. 
Table (4): Effect of different biochar rates on germination percentage, germination rate and coefficient germination velocity of tomato, sweet pepper, cucumber and lettuce in 2018 and 2019 seasons.

\begin{tabular}{|c|c|c|c|c|c|c|}
\hline \multirow{3}{*}{ Treatments } & \multicolumn{6}{|c|}{ Tomato } \\
\hline & \multicolumn{2}{|c|}{$\underset{\%}{\text { Germination }}$} & \multicolumn{2}{|c|}{$\begin{array}{c}\text { Germination rate } \\
\text { day }\end{array}$} & \multicolumn{2}{|c|}{$\begin{array}{c}\text { Coefficient } \\
\text { germination velocity } \\
\%\end{array}$} \\
\hline & 2018 & 2019 & 2018 & 2019 & 2018 & 2019 \\
\hline 0\% biochar (control) & $84.50 \mathrm{c}$ & 83.00 b & $11.94 c$ & $11.67 \mathrm{c}$ & 8.38 a & $8.58 \mathrm{a}$ \\
\hline $20 \%$ biochar & 92.00 a & 90.00 a & $12.27 \mathrm{~b}$ & $12.55 \mathrm{~b}$ & $8.14 \mathrm{a}$ & 8.09 a \\
\hline $40 \%$ biochar & $85.83 \mathrm{~b}$ & $80.67 \mathrm{c}$ & $12.41 \mathrm{~b}$ & $12.60 \mathrm{~b}$ & $8.08 \mathrm{a}$ & $8.02 \mathrm{a}$ \\
\hline \multirow[t]{2}{*}{ 60\% biochar } & $82.33 \mathrm{~d}$ & $76.50 \mathrm{~d}$ & $16.31 \mathrm{a}$ & $16.55 \mathrm{a}$ & $6.20 \mathrm{~b}$ & $6.14 \mathrm{~b}$ \\
\hline & \multicolumn{6}{|c|}{ Sweet pepper } \\
\hline 0\% biochar (control) & 56.81 c & $61.36 \mathrm{~d}$ & $11.96 \mathrm{a}$ & $12.37 \mathrm{a}$ & $8.35 \mathrm{~b}$ & $7.90 \mathrm{~b}$ \\
\hline $20 \%$ biochar & 85.63 a & 86.36 b & $10.60 \mathrm{~b}$ & $10.71 \mathrm{~b}$ & $9.43 \mathrm{a}$ & $9.34 \mathrm{a}$ \\
\hline $40 \%$ biochar & 86.33 a & 88.63 a & $10.74 \mathrm{~b}$ & $10.75 \mathrm{ab}$ & $9.31 \mathrm{a}$ & $9.30 \mathrm{a}$ \\
\hline \multirow[t]{2}{*}{$60 \%$ biochar } & $63.63 \mathrm{~b}$ & $64.77 \mathrm{c}$ & 11.09 a & $11.10 \mathrm{ab}$ & $9.02 \mathrm{a}$ & $9.01 \mathrm{a}$ \\
\hline & \multicolumn{6}{|c|}{ Cucumber } \\
\hline 0\% biochar (control) & $97.63 \mathrm{a}$ & $95.27 \mathrm{a}$ & $6.58 \mathrm{c}$ & $6.32 \mathrm{~b}$ & 15.27 a & $15.83 \mathrm{a}$ \\
\hline $20 \%$ biochar & $97.62 \mathrm{a}$ & $95.24 \mathrm{a}$ & $6.51 \mathrm{c}$ & $6.27 \mathrm{~b}$ & $15.38 \mathrm{a}$ & 15.95 a \\
\hline $40 \%$ biochar & 88.89 b & 88.10 b & $6.84 \mathrm{~b}$ & 7.07ab & $14.67 \mathrm{ab}$ & $14.17 \mathrm{ab}$ \\
\hline \multirow[t]{2}{*}{ 60\% biochar } & $74.26 \mathrm{c}$ & $70.67 \mathrm{c}$ & $7.76 \mathrm{a}$ & $7.68 \mathrm{a}$ & $13.24 \mathrm{~b}$ & $13.02 \mathrm{~b}$ \\
\hline & \multicolumn{6}{|c|}{ Lettuce } \\
\hline 0\% biochar (control) & 84.29 b & 81.90 a & 6.21c & $5.83 \mathrm{c}$ & 16.61 a & $17.16 \mathrm{a}$ \\
\hline $20 \%$ biochar & 86.67 a & 81.51 a & $5.95 \mathrm{c}$ & $5.74 \mathrm{c}$ & $16.93 \mathrm{a}$ & $17.56 \mathrm{a}$ \\
\hline $40 \%$ biochar & $47.78 \mathrm{c}$ & 46.19 b & $8.33 \mathrm{~b}$ & $6.90 \mathrm{~b}$ & $12.80 \mathrm{~b}$ & $14.74 \mathrm{~b}$ \\
\hline $60 \%$ biochar & $42.22 \mathrm{~d}$ & $40.83 \mathrm{c}$ & 11.57 a & 10.71 a & $8.92 \mathrm{c}$ & 9.33c \\
\hline
\end{tabular}

Values in the same column followed by the same letter(s) do not significantly differ from each other according to Duncan's multiple range test at 5\% level

\section{I.2. Vegetative growth, roots growth characters and leaf chlorophyll concentration of tomato, sweet pepper, cucumber and lettuce seedlings.}

\section{I.2.1-Tomato}

Vegetative growth and root growth characters determined at seedling transplanting stage of tomato as grown in the nursery are shown in Tables (5 and 6)the data revealed that, the seedlings growing in media with $20 \%$ biochar addition and irrigated daily or two days registered the highest values of seedling length, stem diameter, fresh weight/ seedling followed by using aqueous extract of biochar at $2 \%$ as foliar spray and irrigation daily or two days treatments in both growing seasons. It is clear that adding the low rate of biochar (20\%) to growing media and irrigation daily or two days significantly positive affected on all abovious vegetative growth and root growth characters, this was true in both growing season except seedling leaf chlorophyll concentration, which the plants growing in media with $60 \%$ biochar addition and irrigated daily or two days gave the highest values. Regarding to number of leaves, it is noticed that, all treatments gave not significant value in both growing season. 
Table (5): Effect of different biochar rates on some vegetative growth characters and leaf chlorophyll $\Xi$ concentration of tomato seedling during 2018 and 2019 seasons

\begin{tabular}{|c|c|c|c|c|c|c|c|c|c|c|}
\hline \multirow[t]{2}{*}{ Treatments } & \multicolumn{2}{|c|}{$\begin{array}{l}\text { Seedling length } \\
(\mathbf{c m})\end{array}$} & \multicolumn{2}{|c|}{$\begin{array}{l}\text { Stem diameter } \\
(\mathrm{cm})\end{array}$} & \multicolumn{2}{|c|}{$\begin{array}{l}\text { No. of. leaves } \\
\text { / Seedling }\end{array}$} & \multicolumn{2}{|c|}{$\begin{array}{l}\text { Fresh weight } \\
\text { g/ Seedling }\end{array}$} & \multicolumn{2}{|c|}{$\begin{array}{c}\text { leaf chlorophyll } \\
\text { concentration SPAD }\end{array}$} \\
\hline & 2018 & 2019 & 2018 & 2019 & 2018 & 2019 & 2018 & 2019 & 2018 & 2019 \\
\hline $\begin{array}{l}\text { Daily irrigation } \\
\text { 0\% biochar (control) }\end{array}$ & $13.48 \mathrm{~d}$ & $14.75 \mathrm{c}$ & $2.54 \mathrm{e}$ & $2.48 \mathrm{e}$ & 3.74 abc & $3.83 \mathrm{~b}$ & $1.80 \mathrm{~d}$ & $1.99 \mathrm{f}$ & 28.60 cdef & 28.20 de \\
\hline $20 \%$ biochar & 18.32 a & 19.66 a & $2.99 \mathrm{a}$ & 3.17 a & $4.66 \mathrm{a}$ & $5.33 \mathrm{a}$ & $3.22 \mathrm{a}$ & $4.14 \mathrm{a}$ & $29.30 \mathrm{~cd}$ & 29.00 bcde \\
\hline $40 \%$ biochar & $14.55 \mathrm{~cd}$ & $15.33 \mathrm{c}$ & 2.65 cde & $2.86 \mathrm{c}$ & $4.41 \mathrm{ab}$ & $4.71 \mathrm{ab}$ & $2.17 \mathrm{~cd}$ & $2.86 \mathrm{~d}$ & $27.30 \mathrm{f}$ & 28.00 e \\
\hline $60 \%$ biochar & $5.80 \mathrm{f}$ & $11.25 \mathrm{~d}$ & $2.15 \mathrm{~g}$ & $2.28 \mathrm{f}$ & $3.33 \mathrm{c}$ & $3.66 \mathrm{~b}$ & 0.99 f & $1.48 \mathrm{~h}$ & 31.95 a & 31.70 a \\
\hline $2 \%$ biochar extract & $16.70 \mathrm{ab}$ & $17.13 \mathrm{~b}$ & 2.79 bc & $2.90 \mathrm{c}$ & 4.33 abc & $4.83 \mathrm{ab}$ & 2.81 ab & $2.95 \mathrm{c}$ & 28.15 def & 28.16 de \\
\hline $4 \%$ biochar extract & $13.22 \mathrm{~d}$ & $14.71 \mathrm{c}$ & $2.60 \mathrm{de}$ & $2.59 \mathrm{de}$ & 3.82 abc & 4.16 ab & $1.87 \mathrm{~d}$ & $2.03 \mathrm{f}$ & 29.00 cde & 28.90 bcde \\
\hline$\frac{\text { Irrigation every two days }}{0 \% \text { biochar }}$ & 15.95 bc & $17.70 \mathrm{~b}$ & $2.74 \mathrm{~cd}$ & $2.89 \mathrm{c}$ & 4.37 abc & $4.80 \mathrm{ab}$ & $2.43 \mathrm{bc}$ & $3.01 \mathrm{c}$ & $27.06 \mathrm{f}$ & 28.10 e \\
\hline $20 \%$ biochar & $16.75 \mathrm{~b}$ & 18.40 ab & 2.97 a & $3.05 \mathrm{ab}$ & 4.35 abc & $4.80 \mathrm{ab}$ & 2.88 ab & $3.49 \mathrm{~b}$ & 27.40 ef & $28.40 \mathrm{de}$ \\
\hline $40 \%$ biochar & $13.70 \mathrm{~d}$ & $14.00 \mathrm{c}$ & $2.59 \mathrm{e}$ & $2.71 \mathrm{f}$ & 4.15 abc & $4.80 \mathrm{ab}$ & $1.96 \mathrm{~cd}$ & $2.24 \mathrm{e}$ & $29.90 \mathrm{bc}$ & 29.60 bed \\
\hline $60 \%$ biochar & $9.22 \mathrm{e}$ & $11.55 \mathrm{~d}$ & $2.30 \mathrm{f}$ & $2.24 \mathrm{~d}$ & $3.38 \mathrm{bc}$ & $3.77 \mathrm{~b}$ & 1.22 ef & $1.64 \mathrm{~g}$ & $31.40 \mathrm{ab}$ & 30.20 abc \\
\hline $2 \%$ biochar extract & $16.55 \mathrm{~b}$ & $17.84 \mathrm{~b}$ & 2.92 ab & $3.03 \mathrm{~b}$ & 4.22 abc & $4.30 \mathrm{ab}$ & $2.74 \mathrm{ab}$ & $2.83 \mathrm{~d}$ & 28.70 cdef & 28.70 cde \\
\hline $4 \%$ biochar extract & $14.80 \mathrm{~cd}$ & $15.30 \mathrm{c}$ & $2.58 \mathrm{e}$ & $2.68 \mathrm{~d}$ & 3.83 abc & 4.00 ab & $1.72 \mathrm{de}$ & $2.16 \mathrm{e}$ & 31.10 ab & $30.40 \mathrm{ab}$ \\
\hline
\end{tabular}

Values in the same column followed by the same letter(s) do not significantly differ from each other according to Duncan's multiple range test at $5 \%$ level 
Table (6): Effect of different biochar rates on some root growth characters of tomato seedling during 2018 and 2019 seasons

\begin{tabular}{|c|c|c|c|c|c|c|}
\hline \multirow[t]{2}{*}{ treatments } & \multicolumn{2}{|c|}{$\begin{array}{l}\text { Root length } \\
\text { ( cm) }\end{array}$} & \multicolumn{2}{|c|}{$\begin{array}{c}\text { Root volume } \\
\left(\mathrm{cm}^{3}\right)\end{array}$} & \multicolumn{2}{|c|}{$\begin{array}{c}\text { Fresh weight } \\
\text { g /root }\end{array}$} \\
\hline & 2018 & 2019 & 2018 & 2019 & 2018 & 2019 \\
\hline$\frac{\text { Daily irrigation }}{\text { 0\% biochar (control) }}$ & $7.60 \mathrm{de}$ & $6.88 \mathrm{~cd}$ & 0.62 de & $0.58 \mathrm{~d}$ & $0.44 \mathrm{~d}$ & 0.38 e \\
\hline $20 \%$ biochar & $9.27 \mathrm{~b}$ & $8.74 \mathrm{~b}$ & 0.92 a & 0.96 a & $0.57 \mathrm{~b}$ & $0.69 \mathrm{~b}$ \\
\hline $40 \%$ biochar & 7.00 ef & 7.94 bc & 0.62 de & $0.58 \mathrm{~d}$ & $0.46 \mathrm{~d}$ & $0.48 \mathrm{~d}$ \\
\hline $60 \%$ biochar & $4.03 \mathrm{~g}$ & $6.81 \mathrm{~cd}$ & $0.24 \mathrm{~g}$ & 0.33 e & $0.13 \mathrm{f}$ & $0.23 \mathrm{f}$ \\
\hline $2 \%$ biochar extract & $8.31 \mathrm{~cd}$ & 7.96 bc & 0.83 bc & 0.89 b & 0.51 bed & $0.55 \mathrm{~cd}$ \\
\hline $4 \%$ biochar extract & $7.95 \mathrm{~d}$ & $7.79 \mathrm{~cd}$ & $0.33 \mathrm{f}$ & 0.33 e & 0.32 e & 0.36 e \\
\hline$\frac{\text { Irrigation every two days }}{0 \% \text { biochar }}$ & 6.90 ef & $6.80 \mathrm{~cd}$ & $0.66 \mathrm{~d}$ & $0.66 \mathrm{c}$ & $0.47 \mathrm{~cd}$ & $0.51 \mathrm{~d}$ \\
\hline $20 \%$ biochar & 10.32 a & 10.90 a & 0.89 ab & 0.91 ab & 0.66 a & $0.78 \quad$ a \\
\hline $40 \%$ biochar & $6.69 \mathrm{f}$ & $7.08 \mathrm{~cd}$ & 0.60 de & $0.62 \mathrm{~cd}$ & $0.43 \mathrm{~d}$ & $0.50 \mathrm{~d}$ \\
\hline $60 \%$ biochar & $4.00 \mathrm{~g}$ & $5.45 \mathrm{~d}$ & $0.16 \mathrm{~h}$ & 0.16 f & $0.16 \mathrm{f}$ & $0.23 \mathrm{f}$ \\
\hline $2 \%$ biochar extract & 8.94 bc & 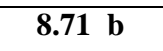 & 0.78 c & $0.66 \mathrm{c}$ & 0.55 bc & $0.59 \mathrm{c}$ \\
\hline $4 \%$ biochar extract & 7.02 ef & 7.25 bc & $0.58 \mathrm{e}$ & $0.58 \mathrm{~d}$ & $0.47 \mathrm{~cd}$ & $0.54 \mathrm{~cd}$ \\
\hline
\end{tabular}

Duncan's multiple range test at $5 \%$ level 


\section{I.2.2. Sweet pepper}

The data in Table (7) registered that, the effect of used different rates of biochar under two periods of irrigation induced significant effect on all vegetative growth, root growth parameters and leaf chlorophyll concentration except stem diameter of sweet pepper seedling as grown in the nursery. It can be observed that with all biochar rates except addition the high rate of biochar $(60 \%)$ to growing media which induced significantly negative affected on all obvious vegetative growth and root growth characters, this was true in both growing season.In other word it can be said that, the best treatments were under foliar spray by aqueous extract of biochar at 4\%,2\% followed by $40 \%$ and $20 \%$ biochar addition to growing media, respectively.

\section{I.2.3.Cucumber}

The data recorded in Table (8) showed that, the effect of used different rates of biochar under two periods every one or two days of irrigation induced significant effect on all vegetative growth. It is quite clear from the data presented that, the seedlings growing in media with $20 \%$ biochar addition and irrigated daily followed by seedlings sprayed by aqueous extract of biochar at $4 \%$ and irrigated daily gave the highest values of seedling length in both growing seasons. According to stem diameter, number of leaves/ seedling, fresh weight/ seedling, data showed that, the best treatments were with $20 \%$ biochar addition to growing media with daily irrigation or spraying seedling by aqueous extract of biochar at $2 \%$ or at $4 \%$ and daily irrigation or two days in both growing seasons.

Regarding to root growth parameter and leaf chlorophyll concentration the data in Table (9) showed that, the seedlings growing in media with $20 \%$ biochar addition and irrigated daily gave the highest values of root volume, fresh weight / root. In addition, the best treatments were addition $20 \%$ or $40 \%$ biochar to growing media and irrigation every two days as well as leaf chlorophyll concentration. While, it is clear that, the best treatments were at addition $40 \%$ biochar to growing media and irrigation every two day or spraying seedling by aqueous extract of biochar at $4 \%$ and irrigation daily, whereas the two treatments gave the highest values ofroot length. These results were true in both growing seasons. 
Table (7): Effect of different biochar rates on some vegetative and root growth characters as well as leaf chlorophyll concentration of sweet pepper seedling during 2018 and 2019 seasons

\begin{tabular}{|c|c|c|c|c|c|c|c|c|c|c|c|c|c|c|}
\hline \multirow[t]{2}{*}{ Treatments } & \multicolumn{2}{|c|}{$\begin{array}{l}\text { Seedling length } \\
\text { ( cm) }\end{array}$} & \multicolumn{2}{|c|}{$\begin{array}{l}\text { Stem diameter } \\
(\mathrm{cm})\end{array}$} & \multicolumn{2}{|c|}{$\begin{array}{l}\text { No. of. leaves } \\
\text { / Seedling }\end{array}$} & \multicolumn{2}{|c|}{$\begin{array}{l}\text { Fresh weight } \\
\text { g / Seedling }\end{array}$} & \multicolumn{2}{|c|}{$\begin{array}{c}\text { Root volume } \\
\left(\mathrm{cm}^{3}\right)\end{array}$} & \multicolumn{2}{|c|}{$\begin{array}{c}\text { Fresh weight } \\
\text { g/Root }\end{array}$} & \multicolumn{2}{|c|}{$\begin{array}{l}\text { leaf chlorophyll } \\
\text { concentration } \\
\text { SPAD }\end{array}$} \\
\hline & 2018 & 2019 & 2018 & 2019 & 2018 & 2019 & 2018 & 2019 & 2018 & 2019 & 2018 & 2019 & 2018 & 2019 \\
\hline$\frac{\text { Daily irrigation }}{\text { 0\% biochar (control) }}$ & $9.40 \mathrm{~h}$ & $9.80 \mathrm{~g}$ & $0.17 \mathrm{~b}$ & $0.15 b$ & $4.75 \mathrm{~d}$ & $5.25 \mathrm{efg}$ & $1.40 \mathrm{de}$ & 1.50 ef & $0.33 \mathrm{c}$ & $0.33 \mathrm{~b}$ & $0.32 \mathrm{de}$ & $0.43 \mathrm{de}$ & 32.401 & $31.00 \mathrm{i}$ \\
\hline $20 \%$ biochar & $10.70 \mathrm{e}$ & $11.10 \mathrm{~d}$ & 0.28 ab & $0.25 \mathrm{ab}$ & $5.14 \mathrm{~cd}$ & 5.40 def & $1.60 \mathrm{c}$ & $1.80 \mathrm{~d}$ & $0.66 \mathrm{a}$ & $0.66 \mathrm{a}$ & 0.47 bcd & 0.56 bc & $35.10 \mathrm{j}$ & $35.50 \mathrm{gh}$ \\
\hline $40 \%$ biochar & $11.50 \mathrm{c}$ & $11.50 \mathrm{c}$ & $0.20 \mathrm{ab}$ & 0.19ab & $5.00 \mathrm{~cd}$ & 5.55 cde & $1.50 \mathrm{~cd}$ & $1.60 \mathrm{e}$ & $0.67 \mathrm{a}$ & $0.67 \mathrm{a}$ & 0.51 bc & $0.61 \mathrm{~b}$ & $35.50 \mathrm{i}$ & $35.90 \mathrm{~g}$ \\
\hline $60 \%$ biochar & $10.20 \mathrm{f}$ & $10.80 \mathrm{e}$ & $0.20 \mathrm{ab}$ & $0.20 \mathrm{ab}$ & $4.75 \mathrm{~d}$ & 5.50 cde & $1.60 \mathrm{c}$ & $1.90 \mathrm{~d}$ & $0.66 \mathrm{a}$ & $0.66 \mathrm{a}$ & 0.49 bc & 0.53 bed & $34.50 \mathrm{k}$ & $35.30 \mathrm{~h}$ \\
\hline $2 \%$ biochar extract & $12.50 \mathrm{~b}$ & $14.30 \mathrm{a}$ & $0.24 \mathrm{ab}$ & $0.22 \mathrm{ab}$ & $5.12 \mathrm{~cd}$ & 5.75 bcd & $2.30 \mathrm{~b}$ & $2.80 \mathrm{a}$ & $0.58 \mathrm{ab}$ & $0.66 \mathrm{a}$ & $0.86 \mathrm{a}$ & $1.14 \mathrm{a}$ & $36.60 \mathrm{~h}$ & $37.90 \mathrm{f}$ \\
\hline $4 \%$ biochar extract & $13.60 \mathrm{a}$ & $14.40 \mathrm{a}$ & $0.30 \mathrm{a}$ & 0.29 a & $5.33 \mathrm{bc}$ & 5.80 bc & $2.70 \mathrm{a}$ & $2.90 \mathrm{a}$ & 0.67 a & $0.67 \mathrm{a}$ & 0.94 a & 1.17 a & $38.10 \mathrm{~g}$ & $39.00 \mathrm{e}$ \\
\hline $\begin{array}{l}\text { Irrigation every two } \\
\frac{\text { days }}{0 \% \text { biochar }}\end{array}$ & $9.30 \mathrm{~h}$ & $9.40 \mathrm{~h}$ & $0.20 \mathrm{ab}$ & $0.20 \mathrm{ab}$ & $4.73 \mathrm{~d}$ & $5.11 \mathrm{fg}$ & $1.10 \mathrm{f}$ & $1.20 \mathrm{~g}$ & $0.33 \mathrm{c}$ & $0.33 \mathrm{~b}$ & $0.30 \mathrm{e}$ & 0.45 de & $38.90 \mathrm{f}$ & $37.60 \mathrm{f}$ \\
\hline $20 \%$ biochar & $9.60 \mathrm{~g}$ & $10.00 \mathrm{fg}$ & $0.20 \mathrm{ab}$ & $0.20 \mathrm{ab}$ & $4.90 \mathrm{~cd}$ & $5.37 \mathrm{efg}$ & $1.50 \mathrm{~cd}$ & $1.95 \mathrm{~d}$ & $0.53 \mathrm{ab}$ & $0.66 \mathrm{a}$ & 0.40 cde & 0.51 bed & $42.20 \mathrm{~d}$ & $41.40 \mathrm{~d}$ \\
\hline $40 \%$ biochar & $9.70 \mathrm{~g}$ & $10.10 \mathrm{f}$ & $0.20 \mathrm{ab}$ & $0.20 \mathrm{ab}$ & $5.00 \mathrm{~cd}$ & 5.44 cdef & $1.30 \mathrm{e}$ & $1.40 \mathrm{f}$ & $0.54 \mathrm{ab}$ & $0.66 \mathrm{a}$ & 0.45 bed & 0.53 bed & $48.30 \mathrm{a}$ & $47.50 \mathrm{~b}$ \\
\hline $60 \%$ biochar & \begin{tabular}{|l|}
$9.30 \mathrm{~h}$ \\
\end{tabular} & $9.50 \mathrm{~h}$ & $0.19 \mathrm{ab}$ & $0.18 \mathrm{~b}$ & $4.93 \mathrm{~cd}$ & $5.00 \mathrm{~g}$ & $1.30 \mathrm{e}$ & 1.50 ef & $0.33 \mathrm{c}$ & $0.33 \mathrm{~b}$ & 0.42bcde & 0.49 de & $40.80 \mathrm{e}$ & $41.50 \mathrm{~d}$ \\
\hline $2 \%$ biochar extract & $10.90 \mathrm{~d}$ & $11.10 \mathrm{~d}$ & $0.21 \mathrm{ab}$ & $0.20 \mathrm{ab}$ & $6.00 \mathrm{a}$ & $6.44 \mathrm{a}$ & $2.20 \mathrm{~b}$ & $2.40 \mathrm{c}$ & 0.49 bc & $0.58 \mathrm{a}$ & 0.49 bc & 0.55 bc & $46.20 \mathrm{c}$ & $47.00 \mathrm{c}$ \\
\hline $4 \%$ biochar extract & $11.40 \mathrm{c}$ & $12.20 \mathrm{~b}$ & $0.22 \mathrm{ab}$ & $0.21 \mathrm{ab}$ & $5.75 \mathrm{ab}$ & $6.00 \mathrm{~b}$ & $2.20 \mathrm{~b}$ & $2.60 \mathrm{~b}$ & $0.66 \mathrm{a}$ & $0.66 \mathrm{a}$ & $0.56 \mathrm{~b}$ & $0.62 \mathrm{~b}$ & $46.70 \mathrm{~b}$ & $48.40 \mathrm{a}$ \\
\hline
\end{tabular}

Values in the same column followed by the same letter(s) do not significantly differ from each other according to Duncan's multiple range test at 5\% level 
Table (8): Effect of different biochar rates on some vegetative growth characters of cucumber seedling during 2018

\begin{tabular}{|c|c|c|c|c|c|c|c|c|}
\hline \multirow[t]{2}{*}{ Treatments } & \multicolumn{2}{|c|}{$\begin{array}{l}\text { Seedling length } \\
\text { ( cm) }\end{array}$} & \multicolumn{2}{|c|}{$\begin{array}{l}\text { Stem diameter } \\
(\mathrm{cm})\end{array}$} & \multicolumn{2}{|c|}{$\begin{array}{l}\text { No. of. leaves } \\
\text { / Seedling }\end{array}$} & \multicolumn{2}{|c|}{$\begin{array}{l}\text { Fresh weight } \\
\text { g / Seedling }\end{array}$} \\
\hline & 2018 & 2019 & 2018 & 2019 & 2018 & 2019 & 2018 & 2019 \\
\hline$\frac{\text { Daily irrigation }}{\text { 0\% biochar (control) }}$ & $16.67 \mathrm{~cd}$ & $16.70 \mathrm{~d}$ & 0.39 de & 0.38 e & $3.57 \mathrm{ab}$ & $3.00 \mathrm{ab}$ & $3.92 \mathrm{e}$ & $3.76 \mathrm{c}$ \\
\hline $20 \%$ biochar & 20.80 a & 20.73 a & $0.43 \mathrm{a}$ & $0.42 \mathrm{~b}$ & $4.00 \mathrm{a}$ & $3.83 \mathrm{a}$ & $4.83 \mathrm{a}$ & $4.80 \mathrm{a}$ \\
\hline $40 \%$ biochar & $17.10 \mathrm{c}$ & $17.40 \mathrm{c}$ & $0.43 \mathrm{a}$ & 0.39 de & 3.17 ab & $3.33 \mathrm{a}$ & $4.08 \mathrm{~d}$ & $4.30 \mathrm{~b}$ \\
\hline $60 \%$ biochar & $11.30 \mathrm{i}$ & $13.48 \mathrm{~g}$ & $0.29 \mathrm{~h}$ & 0.39 de & $2.00 \mathrm{c}$ & $2.00 \mathrm{~b}$ & $1.22 \mathrm{i}$ & $1.03 \mathrm{f}$ \\
\hline $2 \%$ biochar extract & $16.40 \mathrm{~d}$ & $16.90 \mathrm{~d}$ & 0.41 bc & 0.38 e & $4.00 \mathrm{a}$ & $3.83 \mathrm{a}$ & $4.78 \mathrm{a}$ & $4.69 \mathrm{a}$ \\
\hline $4 \%$ biochar extract & $19.60 \mathrm{~b}$ & $18.40 \mathrm{~b}$ & $0.42 \mathrm{ab}$ & 0.41 bc & $4.00 \mathrm{a}$ & 3.83 a & $4.76 \mathrm{a}$ & $4.69 \mathrm{a}$ \\
\hline $\begin{array}{l}\text { Irrigation every two days } \\
0 \% \text { biochar }\end{array}$ & $15.71 \mathrm{e}$ & $15.20 \mathrm{f}$ & 0.39 de & 0.38 e & $3.65 \mathrm{ab}$ & $3.33 \mathrm{a}$ & $4.40 \mathrm{~b}$ & $3.71 \mathrm{c}$ \\
\hline $20 \%$ biochar & $14.20 \mathrm{~g}$ & $15.90 \mathrm{e}$ & $0.40 \mathrm{~cd}$ & $0.40 \mathrm{~cd}$ & $3.15 \mathrm{ab}$ & $3.33 \mathrm{a}$ & $3.45 \mathrm{de}$ & $4.20 \mathrm{~b}$ \\
\hline $40 \%$ biochar & $12.08 \mathrm{~h}$ & $13.70 \mathrm{f}$ & $0.37 \mathrm{f}$ & $0.40 \mathrm{~cd}$ & $3.17 \mathrm{ab}$ & $3.00 \mathrm{ab}$ & $3.25 \mathrm{~g}$ & $3.68 \mathrm{c}$ \\
\hline $60 \%$ biochar & $11.42 \mathrm{i}$ & $9.21 \mathrm{~h}$ & $0.33 \mathrm{~g}$ & $0.31 \mathrm{f}$ & $2.66 \mathrm{bc}$ & $2.00 \mathrm{~b}$ & $2.78 \mathrm{~h}$ & $1.89 \mathrm{e}$ \\
\hline $2 \%$ biochar extract & $16.33 \mathrm{~d}$ & $16.92 \mathrm{~d}$ & 0.43 a & 0.44 a & $4.00 \mathrm{a}$ & $3.50 \mathrm{a}$ & $4.62 \mathrm{c}$ & $4.66 \mathrm{a}$ \\
\hline $4 \%$ biochar extract & $15.06 \mathrm{f}$ & $15.30 \mathrm{f}$ & 0.38 ef & 0.39 de & $4.00 \mathrm{a}$ & $3.66 \mathrm{a}$ & $3.72 \mathrm{f}$ & $3.40 \mathrm{~d}$ \\
\hline
\end{tabular}

Values in the same column followed by the same letter(s) do not significantly differ from each other according to Duncan's multiple range test at $5 \%$ level 
Table (9): Effect of different biochar rates on some root growth characters and leaf chlorophyll concentration of cucumber seedling during 2018 and 2019 seasons.

\begin{tabular}{|c|c|c|c|c|c|c|c|c|}
\hline \multirow[t]{2}{*}{ Treatments } & \multicolumn{2}{|c|}{$\begin{array}{l}\text { Root length } \\
(\mathrm{cm})\end{array}$} & \multicolumn{2}{|c|}{$\begin{array}{c}\text { Root volume } \\
\left(\mathrm{cm}^{3}\right)\end{array}$} & \multicolumn{2}{|c|}{$\begin{array}{c}\text { Fresh weight } \\
\text { g / Root }\end{array}$} & \multicolumn{2}{|c|}{$\begin{array}{c}\text { leaf chlorophyll } \\
\text { concentration (SPAD) }\end{array}$} \\
\hline & 2018 & 2019 & 2018 & 2019 & 2018 & 2019 & 2018 & 2019 \\
\hline$\frac{\text { Daily irrigation }}{\text { 0\% biochar (control) }}$ & $7.00 \mathrm{c}$ & $7.00 \mathrm{~cd}$ & $1.67 \mathrm{a}$ & $1.50 \mathrm{~b}$ & $0.65 \mathrm{~cd}$ & 0.73 cde & $32.90 \mathrm{~h}$ & $34.60 \mathrm{~g}$ \\
\hline $20 \%$ biochar & 8.09 ab & $8.17 \mathrm{a}$ & $1.67 \mathrm{a}$ & $1.67 \mathrm{a}$ & $1.20 \mathrm{a}$ & $1.10 \mathrm{a}$ & $36.98 \mathrm{~d}$ & $39.40 \mathrm{~b}$ \\
\hline $40 \%$ biochar & $7.33 \mathrm{bc}$ & $7.33 \mathrm{bc}$ & $1.00 \mathrm{~d}$ & $1.00 \mathrm{e}$ & $0.80 \mathrm{~b}$ & $0.87 \mathrm{~b}$ & $38.30 \mathrm{c}$ & $38.43 \mathrm{c}$ \\
\hline $60 \%$ biochar & $5.50 \mathrm{f}$ & $4.50 \mathrm{f}$ & 0.78 e & $0.50 \mathrm{~g}$ & 0.75 bc & 0.80 bed & 36.10 & $37.90 \mathrm{~d}$ \\
\hline $2 \%$ biochar extract & $7.50 \mathrm{bc}$ & $7.60 \mathrm{~b}$ & $1.00 \mathrm{~d}$ & $1.00 \mathrm{e}$ & 0.70 bcd & 0.65 ef & $33.80 \mathrm{~g}$ & $35.50 \mathrm{f}$ \\
\hline $4 \%$ biochar extract & 8.70 a & 8.33 a & $1.09 \mathrm{~cd}$ & $1.17 \mathrm{~d}$ & 0.70 bed & 0.67 e & $36.60 \mathrm{de}$ & $35.30 \mathrm{f}$ \\
\hline$\frac{\text { Irrigation every two days }}{0 \% \text { biochar }}$ & $6.17 \mathrm{de}$ & $6.50 \mathrm{de}$ & $1.00 \mathrm{~d}$ & $1.00 \mathrm{e}$ & $0.50 \mathrm{e}$ & $0.53 \mathrm{f}$ & $32.00 \mathrm{i}$ & $35.20 \mathrm{f}$ \\
\hline $20 \%$ biochar & $6.83 \mathrm{~cd}$ & $6.50 \mathrm{de}$ & $1.25 \mathrm{~b}$ & $1.33 \mathrm{c}$ & 0.78 b & 0.83 bc & 40.30 a & 40.00 a \\
\hline $40 \%$ biochar & 8.50 a & 8.50 a & $1.00 \mathrm{~d}$ & $1.00 \mathrm{e}$ & 0.77 bc & $0.70 \mathrm{de}$ & $39.25 \mathrm{~b}$ & $40.01 \mathrm{a}$ \\
\hline $60 \%$ biochar & $6.00 \mathrm{e}$ & $6.00 \mathrm{e}$ & 0.75 e & $0.73 \mathrm{f}$ & 0.70 bcd & 0.70 de & $35.16 \mathrm{f}$ & $36.30 \mathrm{e}$ \\
\hline $2 \%$ biochar extract & $7.34 \mathrm{bc}$ & 7.34 bc & $1.09 \mathrm{~cd}$ & $1.17 \mathrm{~d}$ & $0.65 \mathrm{~cd}$ & 0.70 de & 36.30 e & $35.30 \mathrm{f}$ \\
\hline $4 \%$ biochar extract & 7.42 bc & 7.42 bc & 1.17 bc & $1.33 \mathrm{c}$ & $0.58 \mathrm{de}$ & 0.63 ef & $32.70 \mathrm{~h}$ & $31.40 \mathrm{~h}$ \\
\hline
\end{tabular}

Values in the same column followed by the same letter(s) do not significantly differ from each other according to Duncan's multiple range test at 5\% level 


\section{I.2.4.Lettuce}

Data illustrated in Tables (10 and11) showed that, the seedlings growing in media with $20 \%$ biochar addition and irrigated daily followed by seedlings sprayed by aqueous extract of biochar at $4 \%$ and irrigated daily gave the highest values of seedling length in both growing seasons. While, it is clear that, the best treatments were addition $20 \%$ biochar to growing media and daily irrigation or spraying seedling by aqueous extract of biochar at $4 \%$ and irrigation every two days, whereas the two treatments gave the highest values of number of leaves. These results were true in both growing seasons. According to fresh weight/ seedling, data showed that, the best treatments were with $20 \%$ biochar addition to growing media or spraying seedling by aqueous extract of biochar at $2 \%$ or at $4 \%$ and daily irrigation in both growing seasons. Moreover, it is clear that, foliar spray by aqueous extract of biochar at $2 \%$ or at $4 \%$ and irrigation every two days gave leaf chlorophyll concentration higher than those obtained from daily irrigation. Regarding to stem diameter, it is noticed that, all treatments gave not significant value in both growing season. Data also reported that, adding the low rate of biochar (20\%) to growing media and daily irrigation significantly positive affected on root volume, fresh weight/ root, this was true in both growing season while the plants growing in media with $0 \%$ biochar addition and irrigated every two days gave the highest values of root length.

These results may be due to biochar addition can improve plant growth directly as a result of its nutrient content and release characteristics or indirectly, through improved nutrient retention (Rogovska et al., 2011). Moreover, Biochar contains a high concentration of stable organic carbon (C) as well as eluted carbon some macro, micro elements and ash as shown in Table (3). In this regard A dose-dependent negative effect on germination and seedling growth was found by (Solaiman et al. 2012). The inhibition of seedlings may be attributed to the reduced rate of cell division and cell elongation. On the other hand Northup (2013) showed that, plants grown in biochar containing substrates 30\% [biochar] blended with $70 \%$ sphagnum peat were the best compared to plants grown in a commercial substrate that contained sphagnum peat, perlite, and limestone. Moreover, Haider, et al., (2015) reported that, biochar had an effect on water relations, increasing relative water content and leaf osmotic potential, decreasing stomatal resistance and stimulating foliar (transpiration) gas exchange, and on photosynthesis by increasing the electron transport rate of 
photosystem and the relation between effective photochemical quantum yield and non-photochemical quenching. In this regard, Several macro and micro elements can be stored in the mineral fraction of biochar which may act as a source of mineral substances for microorganisms in the soil (Saletnik et al. 2016). Also, Hafeez et al. (2017) indicated that under water stress, shoot length, chlorophyll contents of soybean seedlings decreased significantly compared to control. However biochar applied proved to be more effective in mitigating the drought stress impacts in all these parameters. Khan et al (2019) reported that, biochar significantly improved shoot and root dry weights, biomass and altered chlorophyll contents of tomato seedlings. Also, Uslu et al. (2020) demonstrated that biochar could increase seedling growth with appropriate application rates.

The second study:

II- Field experiment for planting the sweet pepper seedlings in the field

II.1. Vegetative growth parameters and total yield of sweet pepper plants, whereas obtained from seedlings treated with biochar in the nursery

The vegetative growth parameters of sweet pepper plants and total yield as affected by obvious nursery treatments as shown in the first study are shown in Table (12). The data revealed that, all treatments under investigation gave significantly positive effect on previous characters than the control especially the plants obtained from seedlings sprayed by aqueous extract of biochar at $2 \%$ or at $4 \%$ in both growing seasons. These results may be due to biochar addition can improve plant growth directly as a result of its nutrient content and release characteristics or indirectly, through improved nutrient retention (Rogovska et al., 2011). Moreover, Biochar contains a high concentration of stable organic carbon (C) as well as eluted carbon macro and microelements as shown in Table (3) since it has the capacity to increase nutrient availability in the soil. Generally, biochar has the ability to enhance crop productivity and significantly increases the early growth of seedlings (Thomas and Gale 2015). Several macro and microelements can be stored in the mineral fraction of biochar which may act as a source of mineral substances for microorganisms in soil (Saletnik et al. 2016). Moreover; biochar contains a high concentration of stable organic carbon (C) as well as eluted carbon and ash. Several macro and microelements can be stored in the mineral fraction of biochar which may act as a source of mineral substances for microorganisms in soil (Saletnik et al. 2016). 
Table (10): Effect of different biochar rates on some vegetative growth characters of lettuce seedling during 2018

\begin{tabular}{|c|c|c|c|c|c|c|c|c|}
\hline \multirow[t]{2}{*}{ Treatments } & \multicolumn{2}{|c|}{$\begin{array}{l}\text { Seedling length } \\
\text { ( cm) }\end{array}$} & \multicolumn{2}{|c|}{$\begin{array}{c}\text { Stem diameter } \\
(\mathbf{c m})\end{array}$} & \multicolumn{2}{|c|}{$\begin{array}{l}\text { No. of. leaves } \\
\text { / Seedling }\end{array}$} & \multicolumn{2}{|c|}{$\begin{array}{c}\text { Fresh weight } \\
\text { g / Seedling }\end{array}$} \\
\hline & 2018 & 2019 & 2018 & 2019 & 2018 & 2019 & 2018 & 2019 \\
\hline$\frac{\text { Daily irrigation }}{\text { 0\% biochar (control) }}$ & 16.00 bc & 14.75 de & 0.40 abc & 0.39 bc & 6.67 abc & $7.50 \mathrm{ab}$ & $3.52 \mathrm{~b}$ & 3.05 abc \\
\hline $20 \%$ biochar & 17.73 a & 18.80 a & 0.40 abc & $0.50 \mathrm{a}$ & $7.50 \mathrm{a}$ & 8.40 a & $3.62 \mathrm{a}$ & $3.57 \mathrm{a}$ \\
\hline $40 \%$ biochar & $15.50 \mathrm{c}$ & $14.00 \mathrm{e}$ & 0.40 abc & $0.48 \mathrm{ab}$ & $7.30 \mathrm{ab}$ & $6.50 \mathrm{~cd}$ & $3.10 \mathrm{~d}$ & 3.10 abc \\
\hline $60 \%$ biochar & $12.80 \quad \mathrm{e}$ & $11.90 \mathrm{~g}$ & $0.20 \mathrm{~d}$ & $0.23 \mathrm{~d}$ & $6.00 \mathrm{~cd}$ & $5.00 \mathrm{e}$ & $1.23 \mathrm{~g}$ & $1.89 \mathrm{~d}$ \\
\hline $2 \%$ biochar extract & $15.50 \mathrm{c}$ & $15.00 \mathrm{~d}$ & 0.50 a & $0.50 \mathrm{a}$ & 6.67 abc & $7.00 \mathrm{bc}$ & $3.52 \mathrm{~b}$ & $3.52 \mathrm{ab}$ \\
\hline $4 \%$ biochar extract & 17.30 a & $17.85 \mathrm{~b}$ & 0.50 a & $0.50 \mathrm{a}$ & 7.00 abc & $7.40 \mathrm{bc}$ & $3.52 \mathrm{~b}$ & $3.52 \mathrm{ab}$ \\
\hline$\frac{\text { Irrigation every two days }}{0 \% \text { biochar }}$ & $13.75 \mathrm{~d}$ & $13.00 \mathrm{f}$ & 0.39 bc & $0.38 \mathrm{c}$ & 6.33 bcd & $6.50 \mathrm{~cd}$ & $2.65 \mathrm{e}$ & 2.88 bc \\
\hline $20 \%$ biochar & $14.08 \mathrm{~d}$ & $15.50 \mathrm{~d}$ & 0.38 bc & 0.45 abc & 7.00 abc & $7.40 \mathrm{bc}$ & $3.30 \mathrm{c}$ & 3.30 ab \\
\hline $40 \%$ biochar & $13.75 \mathrm{~d}$ & $13.00 \mathrm{f}$ & $0.36 \mathrm{c}$ & $0.40 \mathrm{bc}$ & 7.00 abc & $6.00 \mathrm{~d}$ & $2.50 \mathrm{f}$ & $2.50 \mathrm{~cd}$ \\
\hline $60 \%$ biochar & $11.00 \mathrm{f}$ & $9.30 \mathrm{~h}$ & $0.18 \mathrm{~d}$ & $0.20 \mathrm{~d}$ & $5.50 \mathrm{~d}$ & $5.00 \mathrm{e}$ & $1.10 \mathrm{~h}$ & $1.10 \mathrm{e}$ \\
\hline $2 \%$ biochar extract & $16.33 \mathrm{~b}$ & $16.83 \mathrm{c}$ & 0.48 ab & 0.46 abc & 7.17 ab & $7.40 \mathrm{bc}$ & $3.28 \mathrm{c}$ & $3.28 \mathrm{ab}$ \\
\hline $4 \%$ biochar extract & $17.20 \mathrm{a}$ & 17.50 bc & $0.47 \mathrm{ab}$ & 0.47 abc & $7.33 \mathrm{ab}$ & $7.50 \mathrm{ab}$ & $3.30 \mathrm{c}$ & $3.30 \mathrm{ab}$ \\
\hline
\end{tabular}

Values in the same column followed by the same letter(s) do not significantly differ from each other according to Duncan's multiple range test at $5 \%$ level 
Table (11): Effect of different biochar rates on some root growth characters and leaf chlorophyll concentration of lettuce seedling during 2018 and 2019 seasons

\begin{tabular}{|c|c|c|c|c|c|c|c|c|}
\hline \multirow[t]{2}{*}{ Treatments } & \multicolumn{2}{|c|}{$\begin{array}{l}\text { Root length } \\
(\mathrm{cm})\end{array}$} & \multicolumn{2}{|c|}{$\begin{array}{c}\text { Root volume } \\
\left(\mathrm{cm}^{3}\right)\end{array}$} & \multicolumn{2}{|c|}{$\begin{array}{l}\text { Fresh weight } \\
\text { g/Root }\end{array}$} & \multicolumn{2}{|c|}{$\begin{array}{c}\text { leaf chlorophyll } \\
\text { concentration SPAD }\end{array}$} \\
\hline & 2018 & 2019 & 2018 & 2019 & 2018 & 2019 & 2018 & 2019 \\
\hline Daily irrigation & $652 \mathrm{~cd}$ & $600 \mathrm{gb}$ & $133 \mathrm{~b}$ & $140 \mathrm{~b}$ & 104 & $097 \mathrm{~cd}$ & $313 \mathrm{~h}$ & 3450 bc \\
\hline $20 \%$ biochar & 6.83 bcd & 6.80 abc & $1.50 \mathrm{a}$ & $1.50 \mathrm{a}$ & $1.60 \mathrm{a}$ & $1.40 \mathrm{a}$ & $34.30 \mathrm{e}$ & 35.00 bc \\
\hline $40 \%$ biochar & $6.50 \mathrm{~cd}$ & 6.00 abc & $1.00 \mathrm{~d}$ & $0.96 \mathrm{~d}$ & $0.90 \mathrm{c}$ & $1.10 \mathrm{~b}$ & $38.60 \mathrm{c}$ & $36.90 \mathrm{ab}$ \\
\hline $60 \%$ biochar & $5.33 \mathrm{e}$ & $5.67 \mathrm{bc}$ & $0.32 \mathrm{f}$ & $0.30 \mathrm{~g}$ & $0.42 \mathrm{~g}$ & $0.39 \mathrm{i}$ & $33.50 \mathrm{~g}$ & 34.90 bc \\
\hline $2 \%$ biochar extract & $7.50 \mathrm{ab}$ & $5.02 \mathrm{c}$ & $1.00 \mathrm{~d}$ & $0.98 \mathrm{~d}$ & 0.85 cd & 0.90 de & $28.50 \mathrm{j}$ & 27.90 e \\
\hline $4 \%$ biochar extract & 7.17 abc & 6.92 ab & $1.25 \mathrm{c}$ & $1.17 \mathrm{c}$ & $1.13 \mathrm{~b}$ & $1.00 \mathrm{c}$ & $28.60 \mathrm{j}$ & $26.53 \mathrm{e}$ \\
\hline$\frac{\text { Irrigation every two days }}{0 \% \text { biochar }}$ & $7.53 \mathrm{ab}$ & $7.59 \mathrm{a}$ & $1.00 \mathrm{~d}$ & 0.88 ef & $0.60 \mathrm{f}$ & $0.70 \mathrm{gh}$ & $33.90 \mathrm{f}$ & $31.20 \mathrm{~d}$ \\
\hline $20 \%$ biochar & $6.42 \mathrm{~cd}$ & 6.83 abc & $1.33 \mathrm{~b}$ & $1.10 \mathrm{c}$ & 0.77 de & 0.77 fg & $36.50 \mathrm{c}$ & 38.40 a \\
\hline $40 \%$ biochar & $6.00 \mathrm{de}$ & 6.25 abc & 0.92 e & $0.84 \mathrm{f}$ & 0.66 ef & $0.66 \mathrm{~h}$ & 39.70 a & 38.00 a \\
\hline $60 \%$ biochar & $4.00 \mathrm{f}$ & $3.20 \mathrm{~d}$ & $0.28 \mathrm{f}$ & $0.28 \mathrm{~g}$ & $0.30 \mathrm{~g}$ & 0.30 i & $39.10 \mathrm{~b}$ & 36.30 abc \\
\hline $2 \%$ biochar extract & $7.83 \mathrm{a}$ & $7.50 \mathrm{a}$ & $1.00 \mathrm{~d}$ & 0.92 de & $0.80 \mathrm{~cd}$ & 0.85 ef & $30.70 \mathrm{i}$ & $33.80 \mathrm{c}$ \\
\hline $4 \%$ biochar extract & 7.00 abc & 6.50 abc & $1.00 \mathrm{~d}$ & $0.99 \mathrm{~d}$ & $0.90 \mathrm{c}$ & 0.85 ef & $31.20 \mathrm{~h}$ & $33.90 \mathrm{c}$ \\
\hline
\end{tabular}

Values in the same column followed by the same letter(s) do not significantly differ from each other according to Duncan's multiple range test at 5\% level 
Table (12): Effect of using different biochar rates in nursery on some vegetative growth characters and total yield of $\tilde{v}$ sweet pepper plant grown in the field during 2018 and 2019 seasons

\begin{tabular}{|c|c|c|c|c|c|c|c|c|c|c|c|c|}
\hline \multirow[t]{2}{*}{ Treatments } & \multicolumn{2}{|c|}{$\begin{array}{l}\text { Plant length } \\
\qquad(\mathrm{cm})\end{array}$} & \multicolumn{2}{|c|}{$\begin{array}{c}\text { Stem diameter } \\
(\mathbf{c m})\end{array}$} & \multicolumn{2}{|c|}{$\begin{array}{c}\text { No. of. } \\
\text { branches/plant }\end{array}$} & \multicolumn{2}{|c|}{$\begin{array}{l}\text { No. of. leaves } \\
\text { / plant }\end{array}$} & \multicolumn{2}{|c|}{$\begin{array}{l}\text { Leaf area } \\
\left(\mathrm{cm}^{2}\right)\end{array}$} & \multicolumn{2}{|c|}{ Total yield ton / fed } \\
\hline & 2018 & 2019 & 2018 & 2019 & 2018 & 2019 & 2018 & 2019 & 2018 & 2019 & 2018 & 2019 \\
\hline$\frac{\text { Daily irrigation }}{\text { 0\% biochar (control) }}$ & $39.00 \mathrm{e}$ & $40.00 \mathrm{e}$ & $1.00 \mathrm{c}$ & $1.00 \mathrm{c}$ & 16.50 de & 19.00 de & $92.00 \mathrm{j}$ & $94.00 \mathrm{k}$ & 326.231 & $328.55 \mathrm{I}$ & $23.52 \mathrm{e}$ & $24.01 \mathrm{e}$ \\
\hline $20 \%$ biochar & $40.30 \mathrm{de}$ & 43.00 bc & $1.20 \mathrm{ab}$ & $1.30 \mathrm{ab}$ & 17.30 de & 19.00 de & $108.50 \mathrm{~h}$ & $117.20 \mathrm{~g}$ & $511.31 \mathrm{e}$ & $556.87 \mathrm{e}$ & 24.18 de & $25.25 \mathrm{de}$ \\
\hline $40 \%$ biochar & $41.40 \mathrm{~cd}$ & 42.50 bed & $1.22 \mathrm{ab}$ & $1.30 \mathrm{ab}$ & $19.80 \mathrm{~b}$ & $20.90 \mathrm{~cd}$ & $111.80 \mathrm{fg}$ & $114.00 \mathrm{hi}$ & $434.60 \mathrm{f}$ & $485.10 \mathrm{f}$ & $25.21 \mathrm{~cd}$ & $24.23 \mathrm{e}$ \\
\hline $60 \%$ biochar & 40.00 de & $42.00 \mathrm{~cd}$ & $1.20 \mathrm{ab}$ & 1.30 ab & $19.30 \mathrm{bc}$ & 20.70 bc & $110.50 \mathrm{~g}$ & $113.00 \mathrm{i}$ & $405.16 \mathrm{i}$ & $424.14 i$ & 24.24 de & $23.71 \mathrm{e}$ \\
\hline $2 \%$ biochar extract & $42.50 \mathrm{c}$ & $44.00 \mathrm{~b}$ & $1.30 \mathrm{a}$ & $1.40 \mathrm{a}$ & $22.00 \mathrm{a}$ & $25.50 \mathrm{a}$ & $158.00 \mathrm{~d}$ & $170.00 \mathrm{~d}$ & $525.26 \mathrm{~d}$ & $602.91 \mathrm{c}$ & 27.57 ab & 26.91 bc \\
\hline $4 \%$ biochar extract & $42.50 \mathrm{c}$ & $44.00 \mathrm{~b}$ & $1.30 \mathrm{a}$ & $1.40 \mathrm{a}$ & $22.40 \mathrm{a}$ & $23.00 \mathrm{~b}$ & $169.00 \mathrm{~b}$ & $181.0 \mathrm{~b}$ & $542.05 \mathrm{c}$ & $626.91 \mathrm{~b}$ & 27.70 ab & 28.09 ab \\
\hline$\frac{\text { Irrigation every two days }}{0 \% \text { biochar }}$ & $40.00 \mathrm{de}$ & $41.10 \mathrm{de}$ & $1.10 \mathrm{bc}$ & $1.20 \mathrm{ab}$ & $17.00 \mathrm{de}$ & $19.00 \mathrm{de}$ & $102.00 \mathrm{i}$ & $107.00 \mathrm{j}$ & $339.31 \mathrm{k}$ & $360.30 \mathrm{k}$ & 23.18 e & $23.96 \mathrm{e}$ \\
\hline $20 \%$ biochar & $41.50 \mathrm{~cd}$ & 43.00bc & $1.20 \mathrm{ab}$ & $1.30 \mathrm{ab}$ & $17.50 \mathrm{de}$ & 19.00 de & $110.70 \mathrm{~g}$ & $115.30 \mathrm{~h}$ & $425.09 \mathrm{~g}$ & $480.44 \mathrm{~g}$ & $24.53 \mathrm{de}$ & $25.05 \mathrm{de}$ \\
\hline $40 \%$ biochar & $40.00 \mathrm{ed}$ & $42.00 \mathrm{~cd}$ & $1.20 \mathrm{ab}$ & $1.20 \mathrm{~b}$ & $16.00 \mathrm{e}$ & $18.00 \mathrm{e}$ & $123.50 \mathrm{e}$ & $135.50 \mathrm{e}$ & $409.35 \mathrm{~h}$ & $434.60 \mathrm{~h}$ & 23.73 de & $25.98 \mathrm{~cd}$ \\
\hline $60 \%$ biochar & $42.50 \mathrm{c}$ & 43.00 bc & $1.10 \mathrm{bc}$ & $1.20 \mathrm{~b}$ & $18.00 \mathrm{~cd}$ & $19.00 \mathrm{de}$ & $112.80 \mathrm{f}$ & $131.30 \mathrm{f}$ & $395.72 \mathrm{j}$ & $414.95 \mathrm{j}$ & $23.71 \mathrm{de}$ & 24.15 e \\
\hline $2 \%$ biochar extract & $45.30 \mathrm{~b}$ & $48.50 \mathrm{a}$ & $1.15 \mathrm{abc}$ & $1.30 \mathrm{ab}$ & $19.50 \mathrm{bc}$ & $21.00 \mathrm{c}$ & $160.50 \mathrm{c}$ & $172.50 \mathrm{c}$ & $557.87 \mathrm{~b}$ & $588.14 d$ & 26.13 bc & $26.30 \mathrm{~cd}$ \\
\hline $4 \%$ biochar extract & $48.00 \mathrm{a}$ & 49.00 a & $1.30 \mathrm{a}$ & $1.30 \mathrm{ab}$ & $23.00 \mathrm{a}$ & 24.00 ab & $184.50 \mathrm{a}$ & 188.00 a & 574.59 a & 629.25 a & 27.76 a & 28.56 a \\
\hline
\end{tabular}

Values in the same column followed by the same letter(s) do not significantly differ from each other according to Duncan's multiple range test at $5 \%$ level 


\section{REFERANCES}

Al-Harbi, A. R. ; M. A. Wahb-Allahand and S.S. Abu-Muriefah (2008). Salinity and Nitrogen Level Affects Germination, Emergence, and Seedling Growth of Tomato. International Journal of Vegetable Science, 14 (4): 4380 - 4392.

Carter,S.;S. Shackley;S. Sohi;T.B. Suy and S. Haefele (2013). The impact of biochar application on soil properties and plant growth of pot grown lettuce (lactuca sativa) and cabbage (brassica chinensis).Agronomy,3(2): 404-418.

Dumroese, R.K. ; J. Heiskanen ; K. Englund and A.Tervahauta(2011). Pelleted biochar: Chemical and physical properties show potential use as a substrate in container nurseries.Biomass Bioenergy., $35: 20-27$.

Ernsting, A. (2011). Biochar a climate change solution. Climate chang.\& Agri., 1: 5-6.

Hafeez, Y. ; S. Iqba ;K. Jabeen ; S. Shahzad ; S. Jahan and F. Rasu(2017).Effect of biochar application on seed germination and seedling growth of glycine max (1.) merr.under drought stress. Pak. J. Bot., 49(SI): 7-13.

Haider, G. ; H.W. Koyro ; F. Azam ; D. Steffens ; C. Müller and C. Kammann (2015). Biochar but not humic acid product amendment affected maize yields via improving plant-soil moisture relations. Plant and Soil. 395:141-157.

Headlee, W.L. ; C.E. Brewer and R.B. Hall (2014). Biochar as a substitute for vermiculite in potting mix for hybrid poplar.Bioenergy Res., 7: 120-131.

Kamara, A. ; A. Kamara ; M. Mansaray and P.Sawyerr(2014). Effects of biochar derived from maize stover and rice straw on the germination of their seeds. American Journal of Agriculture and Forestry, 2(6): 246-249.

Keller, M.L. ; C.A. Masiello ; B. Dugan ; J.A. Rudgers and S.C. Capareda (2010). Phytotoxicity and plant productivity analysis of tar-enriched biochars. American Geophysical Union, Fall Meeting Abstract., 1: pP 481.

Khan, M.N. ; Z. Lan ; T.S.Sial ;Y. Zhao andA.H.Z. Jianguo (2019).Straw and biochar effects on soil properties and tomato seedling growth under different moisture rates. Archives of Agronomy and Soil Science., 65(12): 1704-1719.

Korkmaz, A. and Y. Korkmaz(2009).Promotion by 5-aminolevulenic acid of pepper seed germination and seedling emergence under lowtemperature stress.Hort. Sci.,199: 98-102. 
Kwapinski, W. ; C.M. Byrne ; E. Kryachko ; P. Wolfram ; C.Adley ; J.J. Leahy and M.H.B. Hayes (2010). Biochar from biomass and waste. Waste Biomass Valorization.,1: 177-189.

Landis, T.D. and N. Morgan (2008).Growing Media Alternatives for Forest and Native Plant Nurseries. In Proceedings of the National Proceedings, Forest and Conservation Nursery Associations, Missoula, MT, USA, 23-25.

Lehmann, J. and S. Joseph (2009).Biochar for environmental management.Earthscan publishing, London. Canadian Journal of Soil Science, 92(2): 329- 340.

Matt, C.P. ;C.R. Keyes and R.K. Dumroese (2018).Biochar effects on the nursery propagation of 4 northern Rocky Mountain native plant species. Nativ. Plants J., 19: 14-25.

Michel, J.C. (2010). The physical properties of peat.a key factor for modern growing media, Mires Peat, 6: 1-6.

Nemati, M.R. ; F.Simard ; J. P .Fortin and J. Beaudoin (2015).Potential use of biochar in growing media.Vadose Zone J., Pp 14.

Northup, J. (2013). "Biochar as a replacement for perlite in greenhouse soilless substrates". Iowa State University, Graduate Thesis and Dissertations.,Pp: 13399.

Ranal, M. and D.G.D. Santana(2006).How and why to measure the germination process.RevistaBrasil. Bot., 29(1):1-11

Robertson, S.J. ; P.M. Rutherford ; J.C. Lopez-Gutierrez and H.B.Massicotte (2012). Biochar enhances seedling growth and alters root symbioses and properties of sub-boreal forest soils.Can. J. Soil Sci., 92: 329-340.

Rogovska, N. ;D. Laird ; R.M. Cruse ; S.Trabue and E.Heaton (2011). Germination Tests for Assessing Biochar Quality. J. Environ. Qual., 41: 1014-1022.

Saletnik, B. ; M. Bajcar ; G. Zagula ; M.Czernicka and C. Puchalski(2016). Influence of biochar and biomass ash applied as soil amendment on germination rate of Virginia mallow seeds (Sidahermaphrodita R.).Econtechmod, 5(3): 71-76.

Schmilewski, G. (2008). The Role of peat in assuring the quality of growing media, Mires Peat, 3: 1-8.

Snedecor, G. W. and W. G. Cochran (1982).Statistical Methods, $7^{\text {th }}$ Ed ., The Iowa state Univ., Press, Ames., Iowa, U. S. A.

Sohi, S.P. ; E. Krull ; E.Lopez-Capel and R.Bol(2010). ${ }^{6}$ A review of biochar and its use and function in soil', Advances in Agronomy, 105: 47-82.

Solaiman, Z.M. ; D.V. Murphy and L.K. Abbott (2012). 'Biochars influence seed germination and early growth of seedlings', Plant and Soil, 353: 273-287. 
Soni, N. ; R.G. Leon ; J.E. Erickson ; J.A. Ferrell ; M.L. Silveira and M.C. Giurcanu(2014). Vinasse and biochar effects on germination and growth of palmer Amaranth (Amaranthuspalmeri), Sicklepod (Sennaobtusifolia), and Southern Crabgrass (Digitariaciliaris). Weed Technol., 28: 694-702.

Taek-Keun,O. ; Y. Shinogi ; J. Chikushi ; Y. Lee and B. Choi (2012).Effect of Aqueous Extract of Biochar on Germination and Seedling Growth of Lettuce (Lactuca sativa L.).J. Fac. Agr., Kyushu Univ., 57 (1): 55-60.

Thomas, S. and N. Gale (2015). Biochar and forest restoration: a review and meta-analysis of tree growth responses. New Forests, 46: 931-946.

Uslu, O. S. ; E. Babur ; M.H. Alma and Z.M. Solaiman(2020).Walnut Shell Biochar Increases Seed Germination and Early Growth of Seedlings of Fodder Crops.Agriculture, 10(427): 1- 13.

Van Zwieten. L., S. Kimber, S. Morris, K.Y. Chan, A .Downie, J Rust, A. Cowie, 2010. Effects of biochar from slow pyrolysis of papermill waste on agronomic performance and soil fertility.Plant Soil. 327: 235-246.

Vaughn, S.F. ; F.J.Eller ; R.L. Evangelista ; B.R. Moser and S.C. Peterson (2015). Evaluation of biochar-anaerobic potato digestate mixtures as renewable components of horticultural potting media. Ind. Crop Prod., 65: 467-471.

Wallace,D.H.and H.M.Munger(1965).Studies of the physiological basis for yield differences.1.growth and analysis of six dry bean varieties. Crop Sci.,5:343-348.




المعدل الهنخفض من الفحم النباتى (20٪) إلى بيئة النمو والري كل يوم أوكل يومين أثن تأثير

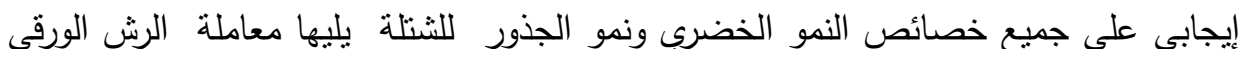

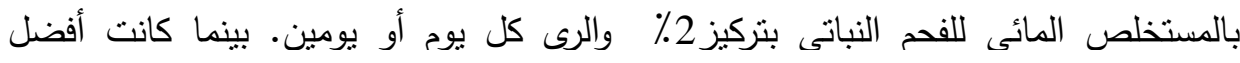

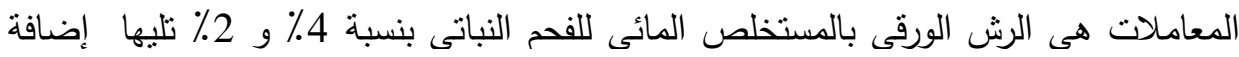

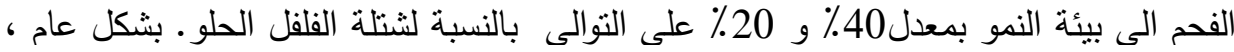

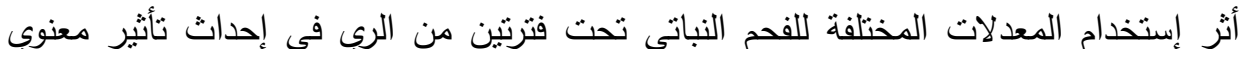

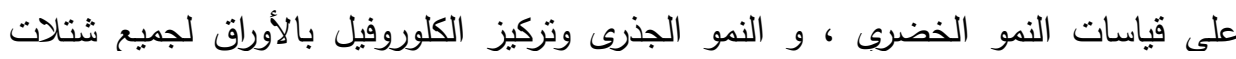

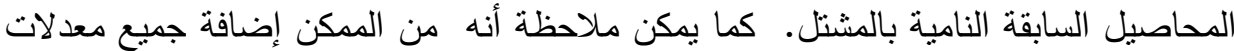


إستثاء المعدل المرتفع (60٪) الذي أثر سلبيًا بشكل كبير على جميع خصائص النمو

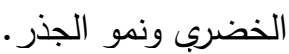

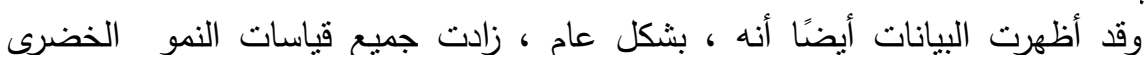

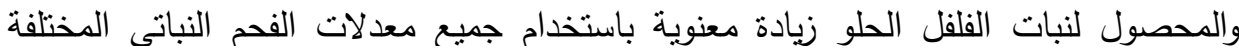

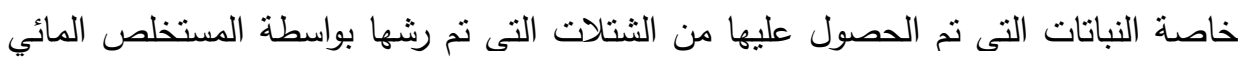

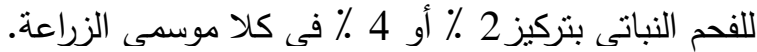

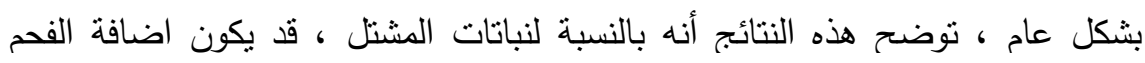

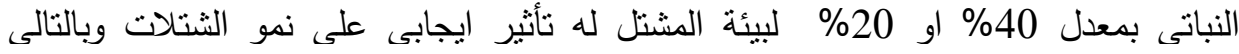
تحسين انتاجية النباتات الناتجة كما يقلل من الإعتماد على مكونات بيئات النموغير المتجددة

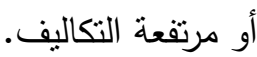

